\title{
CORPORATE IMAGE OF \\ PUBLIC HIGHER EDUCATION INSTITUTIONS: RELEVANT FACTORS TO DISTANCE LEARNING STUDENTS
}

\author{
Fabio R. da COSTA \\ Postgraduate program in Administration \\ Federal University of Espirito Santo \\ Vitoria, Espirito Santo, Brazil \\ Dr. Anderson S. PELISSARI \\ Department of Administration \\ Federal University of Espirito Santo \\ Vitoria, Espirito Santo, Brazil \\ Dr. Inayara V. D. P. GONZALEZ \\ Department of Administration \\ Federal University of Espirito Santo \\ Vitoria, Espirito Santo, Brazil
}

\section{ABSTRACT}

Technological advances are generating a significant increase in the supply of distance learning (DL) courses via the Internet, increasing the importance of this type of education for the university's structure. This article identifies factors associated with perceptions of the public higher education institutions' image from the perspective of DL students. This is a field study that is exploratory, descriptive and quantitative in nature. The units of analysis are institutions in the Higher Education Distance Learning Centre of the state of Rio de Janeiro (Centro de Educacao Superior a Distancia do Estado do Rio de Janeiro CEDERJ) consortium that offer undergraduate courses, and the observation units are students enrolled in the Sao Fidelis Centre (Polo de Sao Fidelis). The data were collected by means of a survey, then tabulated and analyzed using the SPSS program. The results indicate that the image is a snapshot, generated from the current stimuli projected by the organization and translated by the public, based on relevant cognitive and affective aspects, according to the individual's manner of observing the environment. The study demonstrates the multidimensionality of the image and that the studied institutions' global image is associated most strongly with their affective image. Furthermore, the results show that the amount of time that a member of the public interacts with an organisation does not affect her perception of that organization's image.

Keywords: Corporate image, distance learning, higher education, public institution, CEDERJ.

\section{INTRODUCTION}

The environment in which universities operate has become highly competitive (Harsono, 2014), and the education sector has adopted marketing concepts to adapt to this situation (Camelia \& Marius, 2013), demystifying the idea that this sector cannot consider concepts associated with this science such as promotion and sales (Harsono, 2014). In this context, there are also technological changes that have affected education. These have led to a significant increase in the supply of distance learning (DL) via the Internet (Kauffman, 2015). Thus, this type of education has become a fundamental part of the university's structure (Yener, 2013). 
The Anisio Teixeira National Institute of Educational Research and Studies (Instituto Nacional de Estudos e Pesquisas Educacionais Anisio Teixeira - INEP) (2015) corroborates this thinking by noting that the number of enrolments in DL courses increased by $16.3 \%$ between 2013 and 2014. Comparing new entrants in the public network, DL showed an increase of $\mathbf{1 8 . 9 8 \% , ~ w h e r e a s ~ t h e ~ r a t e ~ f o r ~ c l a s s r o o m ~ t e a c h i n g ~ w a s ~}$ $1.96 \%$ (INEP, 2015). This growth has led Mondini, Mondini, da Rosa Borges and de Souza Domingues (2014) to conclude that image is an important element in the management of these courses.

In this sense, Kundi, Nawaz and Khan (2010) argue that the entire DL project, in addition to its form, teaching, environment and tools used in the process, is a function of the perceptions created by its public and that these are a determining element of its success. Such growth challenges educational institutions to create and organize an appropriate administrative and technological infrastructure that facilitates interactivity among faculty, students, and staff, in addition to requiring an emphasis on both their pedagogical proposals and the quality of teaching and learning (Boas, de Andrade, Hamtini \& de Sousa, 2011).

From this perspective, Wilkins and Huisman (2013) state that higher education institutions should turn their interest to developing and maintaining a positive image with students because, as Slavov and Slavov (2010) add, DL brings together students of various backgrounds, interacting in the virtual environment, and as Kucuksuleymanoglu (2015) states, a positive image significantly affects the remaining public of such institutions and collaborates to attract new students.

Given Kauffman's (2015) observation that there is dissonance between the perceptions of DL students and those of students attending classroom-based courses and given that corporate image in the field of non-profit organizations is little explored (Azoury, Daou, \& Khoury, 2014), these reflections lead to the following question: What factors are associated with the public higher education institution's image, from the perspective of students enrolled in DL courses?

Given that there has been little research in the area of DL that measures student-targeted strategies and their effect on the choice of a higher education institution (Mondini, Mondini, da Rosa Borges \& de Souza Domingues, 2014), the objective of this research is to answer this question. To that end, the methodology used is based on the study by Palacio, Meneses and Perez (2002), and of all the variables presented in that study, those that are appropriate to the Brazilian context, the objectives of this research, and the peculiarities of DL are selected. Since the 1990s, there has been a gradual increase in research on the university's corporate image (Kucuksuleymanoglu, 2015). In recent years, Polat (2011), Wilkins and Huisman (2013), Azoury, Daou and Khoury (2014), and da Costa Vieira and Couto (2015) can be cited. In addition, the studies by Spindola and Mousinho (2012), Harsono (2014), and Mondini et al (2014) on distance learning should be highlighted.

Interest in this research is in line with the observation by da Costa and Pelissari (2016), who consider that there is no contradiction in the application of marketing concepts to the world of the non-profit institution, and the analysis by Tran, Nguyen, Melewar and Bodoh (2015), who consider that to develop effective strategies for maintaining a strong corporate image, it is necessary to know the various elements that compose it and that there is a lack of consensus on how to measure image due to the complexity and subjectivity of the construct (Cervera, Schlesinger, Iniesta \& Sánchez, 2012).

Therefore, the aim of this research is to contribute to a better understanding of how the image of higher education institutions is perceived by DL students. Doing so should contribute to the development of strategies to strengthen the image of organizations that provide this means of education. In addition, this research will demonstrate how 
marketing can be used to promote higher education institutions and provide support for future research on the subject.

\section{THEORETICAL REFERENCE}

\section{Corporate Image}

Da Costa Vieira and Couto (2015) argue that the pioneering work of Martineau in his 1958 studies should be considered the starting point for using the concept of image associated with marketing. Martineau (1958) establishes that the attributes of a brand are overridden by the impressions that it creates, in that it incorporates and solidifies an image created in the mind of its public and that this image serves as a decisive factor in the selection process.

Subsequently, Barich and Kotler (1991) establish that an image, whether true or false, real or imagined, can be constructed by a public, given that it is the representation of all impressions, attitudes, and beliefs of a public in regard to an organization. Wilkins and Huisman (2013) add that it is the responsibility of managers to observe how the signs of corporate identity are transmitted and decoded by interested parties in the form of an attractive organisational image.

Nguyen and Leblanc (2001) argue that individuals select and retain in their mind, consciously or unconsciously, realities formed by the company to which they are exposed and that are compatible with their beliefs and behavior; they then recover these realities from their memory to create the corporate image. In turn, Dowling (1986) emphasizes that image is the form by which an institution, brand, or object is known as a result of the individual's perception when entering into contact with it.

Such thinking is also confirmed by Balmer and Grayser (2006), who consider that the corporate image is an answer to the question: "How is the company being perceived now?" Polat (2011) disagrees with this perspective and argues that the image is formed by a process that requires a long period of time.

In this regard, Azoury et al (2014) note that there has been disagreement when attempting to define it. However, despite the various conceptions of image, there is consensus in considering it an impression (Tubillejas, Cuadrado \& Frasquet, 2011; da Costa \& Pelissari, 2016), multidimensional (Dowling, 1986; Barich \& Kotler, 1991; Palacio, Meneses \& Perez, 2002; Cervera, Schlesinger, Iniesta and Sánchez, 2012; Azoury et al, 2014), and based on interactions with the organisation (Polat, 2011; da Costa \& Pelissari, 2016).

In their research with Spanish university students, Palacio, Meneses, and Perez (2002) suggest that the global image is composed of interrelated cognitive and affective aspects and determines user satisfaction with such institutions. Such thinking is corroborated by Azoury et al (2014), who argue that different components compose the corporate image; the affective aspect of the image is associated with the cognitive; and the affective component has the greatest effect on an institution's global image.

It is noteworthy that cognitive components relate to tangible aspects of the organization whereas the feelings related to it and that reflect intangible aspects are addressed by affective components (Palacio et al, 2002; Cervera et al., 2012). The literature review performed has led to the development of four hypotheses to be tested by this research:

H1:The cognitive image of a public higher education institution is significantly associated with its affective image;

H2:The cognitive image of a public higher education institution is significantly associated with its global image;

H3:The affective image of a public higher education institution is significantly associated with its global image; and 
H4:The length of interaction of students with the educational institution significantly affects their perception of the global image of a public higher education institution.

This study adopts the concepts presented by Berens and Van Riel (2004), who establish that the corporate image is a compound formed through the use of products and services, the influence of others, the reputation of the institution, communicative actions, the collective experiences of consumers, and personal insights translated into impressions, beliefs, and feelings in regard to the organization.

To offer a contribution in regard to the factors associated with the image of public higher education institutions, institutions belonging to the Higher Education Distance Learning Centre of the state of Rio de Janeiro (Centro de Educacao Superior a Distancia do Estado do Rio de Janeiro - CEDERJ) consortium were studied. This consortium has a structure that contributes to the understanding of DL models offered by the Open University System (Sistema Universidade Aberta - UAB) (Costa, 2007). Conceptually, DL is an educational modality, with students and professors developing educational activities in different places and at different times, using information and communication technologies (BRASIL, 2005).

\section{The CEDERJ Consortium}

The State Government of Rio de Janeiro created the CEDERJ consortium in 2000 (CEDERJ, 2017). The CEDERJ is a consortium composed of the Federal University of Rio de Janeiro (Universidade Federal do Rio de Janeiro - UFRJ), the Federal Fluminense University (Universidade Federal Fluminense - UFF), the Federal Centre for Technological Education Celso Suckow da Fonseca (Centro Federal de Educacao Tecnologica Celso Suckow da Fonseca - CEFET), Darcy Ribeiro State University of Northern Rio de Janeiro (Universidade Estadual do Norte-Fluminense Darcy Ribeiro - UENF), the State University of Rio de Janeiro (Universidade do Estado do Rio de Janeiro - UERJ), the Federal University of the State of Rio de Janeiro (Universidade Federal do Estado do Rio de Janeiro - UNIRIO) and the Rural Federal University of Rio de Janeiro (Universidade Federal Rural do Rio de Janeiro - UFRRJ) (CEDERJ, 2017).

All consortium institutions are public, and their courses are offered free of charge (Moran, 2009). The CEDERJ consortium covers eight state regions and currently has approximately 45,000 students distributed across 15 courses offered by the consortium in 33 centers (CEDERJ, 2017). The CECIERJ (2017) clarifies that student diplomas are issued with the name of the university offering the course and that the student is considered to have attended that university.

The legal documents establishing the functional structure of DL institutions include the Law of Guidelines and Bases of Education, Law 9,394 of December 1996, Decree 5,773 of June 2006, and Regulatory Ordinances 1 and 2 of 11 January 2007. In general terms, these documents establish the physical infrastructure and staff required for a classroombased center to be accredited by the institution for the provision of DL courses.

The physical structure that houses the centers is mostly provided by city hall, which is also responsible for the appointment of administrative staff (Souza Neto, Dias, Boas, Brito \& Leite, 2010). Within this framework, it is the responsibility of the CECIERJ Foundation Science and Higher Education Distance Learning Centre of the State of Rio de Janeiro (Centro de Ciencias e Educacao Superior a Distancia do Estado do Rio de Janeiro), linked to the State Secretariat of Science and Technology (Secretaria de Estado de Ciencia e Tecnologia), to produce teaching materials and to provide management of the education support platform (Spindola \& Mousinho, 2012).

From an institutional perspective, the CEDERJ consortium forms part of the CECIERJ Foundation; the management of the CEDERJ is performed by the Consortium Management Centre and is completely separate from the consortium's educational 
institutions. The CEDERJ's decision-making is performed by the Course Coordinator Collegiate, the Board of Academic Strategies, and the Superior Council (Costa, 2007).

Souza Neto, Dias, Boas, Brito and Leite (2010) observe that universities are responsible for the pedagogical projects of each course and, as Claro (2007) adds, for the coordination of the courses offered to obtain the same quality as that provided in classroom courses. Assessment is the responsibility of, and prepared by, each course's coordinator and is transmitted to the institutions offering the course at the center (Bielschowsky, 2005).

Claro (2007) notes that members of the tutoring team are required to have graduate or postgraduate education and are not an integral part of the teaching staff of the consortium institutions. The tutors are specialized professionals who meet and monitor students and are guided by professors who are responsible for disciplines or classes. This service occurs in the centers or in consortium universities (CECIERJ, 2017).

The CEDERJ platform provides student resources such as forums, chat rooms, the ability to send messages to other students, communication with professors, schedules of activities, tests, classes, lesson plans, and the opportunity to download support materials for the respective disciplines (Spindola \& Mousinho, 2012). This enables interactivity and integration of the parties involved in the teaching-learning process (Souza Neto et al, 2010).

\section{METHODOLOGICAL ASPECTS OF THE RESEARCH}

This study is quantitative, considering that it allows the relations between phenomenon to be proven and generalization of its occurrence (Lakatos \& Marconi, 2010), and in accordance with Rindfleisch, Malter, Ganesan and Moorman (2008), this research is cross-sectional in nature, given that each interviewed answered the survey a single moment in time.

Yin (2015) states that a study is exploratory when it aims to increase familiarity with and knowledge about a little-known subject and allows the construction of hypotheses. Therefore, the survey method was used. The units of analysis were public higher education institutions in the State of Rio de Janeiro offering undergraduate DL courses within the CEDERJ consortium at the Sao Fidelis Centre.

The state of Rio de Janeiro was chosen, as Claro (2007) notes, because of the pioneering nature of the CEDERJ consortium in making use of print resources, distance tutorials, and classroom tutorials, combined with a virtual learning environment (Claro, 2007), and because of the attention that was given by the Ministry of Education and Culture (2001) to the innovative nature of the CEDERJ project.

The study population included all students enrolled in the second semester of 2014, regardless of area, who started the DL course in the first semester of 2014, to include incoming students, and students enrolled in the second semester of 2014 in the DL course, regardless of area, who had been in the course more than three years, to include graduating students. In both cases, only students regularly enrolled and present in the courses were considered. The Sao Fidelis Centre was chosen for convenience due to the closeness of the researcher to the municipality in which the center is located and the ease of access to information and research sources.

Richardson (1999) notes that one can define the minimum sample size in the case of a finite universe using the following formula:

$$
n=\frac{S^{2} \cdot p \cdot q \cdot N}{e^{2}(N-1)+S^{2} \text { p. q }}
$$


Where:

$\mathrm{n}$ : the sample size;

S: the chosen confidence level in number of standard deviations;

p: the percentage of the sample elements favorable to the phenomenon;

q: the percentage of sample elements unfavorable to the phenomenon, that is, 100-p.

$\mathrm{N}$ : the population size; and

E: the maximum acceptable error estimation, percentage.

A minimum number of 85 respondents was thus established, according to calculation of the following formula:

$$
\mathrm{n}=\frac{2^{2} .50 .50 .108}{5^{2}(108-1)+2^{2} .50 .50}
$$

Chin, Marcolin, and Newsted (2003) note that the sample must be calculated considering as least $\mathbf{1 0}$ respondents multiplied by the number of indicators of the construct with the most indicators. Hair, Anderson, Tatham, and Black (2005) also state that the minimum number of observations for performing a factor analysis is $\mathbf{5 0}$ respondents and, as a rule, there should be a minimum amount of five times more observations than the construct with the most indicators and preferably 10 times more observations. Because, in this study, the construct of "Teaching" is that with the greatest number of indicators, in this case 8 , the number of observations to be achieved would be 80 . Thus, the sample has a number of observations greater than that established by Chin et al (2003) and Hair et al. (2005).

The research used a probabilistic sample, which according to Malhotra (2011), grants all members of the research universe the same chance of selection to compose the sample. The sampling was stratified by course, allowing for a better representation of the population and ensuring the representation of all population groups (Malhotra, 2011). Thus, the percentage of regularly enrolled students per course was used (courses listed in alphabetical order). The sample was composed as shown in Table 1:

Table 1. Composition of the sample stratified by course

\begin{tabular}{ccccccc}
\hline Course & Institution & Incoming & $\%$ & Graduating & $\%$ & Total \\
\hline Administration & UFRRJ & 14 & 37.84 & 12 & 25 & 26 \\
Biology & UENF & 8 & 21.62 & 10 & 20.83 & 18 \\
Computer Sciences & UFF & 2 & 5.26 & 1 & 2.08 & 3 \\
Mathematics & UFF & 2 & 5.26 & 2 & 4.17 & 4 \\
Education & UNIRIO & 10 & 26.32 & 18 & 37.5 & 28 \\
Chemistry & UENF & 1 & 2.63 & 5 & 10.42 & 6 \\
TOTAL & & 37 & 100 & 48 & 100 & 85 \\
\hline
\end{tabular}

Source: The authors (2017).

A structured questionnaire of 37 closed-ended questions was used to measure the variables. For data collection, a six-point Likert scale ranging from 1 to 6 was used. It was of the agree/disagree type. A six-point scale was chosen to avoid the central tendency error, forcing the respondent to position herself as being in agreement or disagreement with the research issues. This measure is based on the studies by Garland (1991), who proves that omission of the central point prevents individuals from giving neutral responses to not displease the researcher with negative responses, which may distort the results of the research.

The 37 variables used to measure cognitive and affective images were based on the research by Palacio et al (2002), adapted for the DL environment and based on the course structure offered by institutions belonging to the CEDERJ consortium. The scale for 
measuring global image was adapted from the study by Tubillejas, Cuadrado and Frasquet (2011).

The variables were operationalized as shown below in Table 2. A pre-test was performed between 14 and 16 October 2014 and was applied to 18 respondents. The questionnaire was administered on 15, 16, 29, and 30 November 2014.

Table 2 Scales used in the collection instrument

\begin{tabular}{|c|c|c|}
\hline \multicolumn{3}{|r|}{ Variables } \\
\hline $\begin{array}{l}\text { General } \\
\text { characteristi } \\
\text { cs of the } \\
\text { institution }\end{array}$ & $\begin{array}{l}\text { V01 } \\
\text { V02 } \\
\text { V03 } \\
\text { V04 } \\
\text { V05 } \\
\text { V06 } \\
\text { V07 }\end{array}$ & $\begin{array}{l}\text { Cognitive image } \\
\text { Ease of entry } \\
\text { Innovative image } \\
\text { Effective advertisements } \\
\text { Consistent communication } \\
\text { Level of entrance exam difficulty } \\
\text { Reputation } \\
\text { Time of existence }\end{array}$ \\
\hline $\begin{array}{c}\text { Virtual } \\
\text { environment }\end{array}$ & $\begin{array}{l}\text { V08 } \\
\text { V09 } \\
\text { V10 } \\
\text { V11 } \\
\text { V12 }\end{array}$ & $\begin{array}{l}\text { Innovative teaching } \\
\text { Ease of access to educational materials } \\
\text { Ease of use of platform } \\
\text { Platform quality } \\
\text { Interface facilitating DL activities }\end{array}$ \\
\hline $\begin{array}{l}\text { Staff and } \\
\text { Tutors }\end{array}$ & $\begin{array}{l}\text { V13 } \\
\text { V14 } \\
\text { V15 } \\
\text { V16 } \\
\text { V17 }\end{array}$ & $\begin{array}{l}\text { Correct information } \\
\text { Willingness to solve problems } \\
\text { Response time } \\
\text { Trained tutors } \\
\text { Qualified tutors }\end{array}$ \\
\hline Teaching & $\begin{array}{l}\text { V18 } \\
\text { V19 } \\
\text { V20 } \\
\text { V21 } \\
\text { V22 } \\
\text { V23 } \\
\text { V24 } \\
\text { V25 }\end{array}$ & $\begin{array}{l}\text { Consistency of disciplines } \\
\text { Curriculum relevant to the labor market } \\
\text { Updated content } \\
\text { Consistent assessments } \\
\text { Assessments compatible with DL } \\
\text { Course level of difficulty } \\
\text { Sufficient practical activities } \\
\text { Preparation for the labor market }\end{array}$ \\
\hline $\begin{array}{l}\text { Services } \\
\text { Provided }\end{array}$ & $\begin{array}{l}\text { V26 } \\
\text { V27 } \\
\text { V28 } \\
\text { V29 } \\
\text { V30 } \\
\text { V31 }\end{array}$ & $\begin{array}{l}\text { Information on services } \\
\text { Quality academic services } \\
\text { Quality administrative services } \\
\text { Services provided to the community } \\
\text { Recognition of society } \\
\text { Improvement of academic services }\end{array}$ \\
\hline Environment & $\begin{array}{l}\text { V32 } \\
\text { V33 } \\
\text { V34 }\end{array}$ & $\begin{array}{l}\text { Affective Image } \\
\text { Environment conducive to communication } \\
\text { Environment conducive to study } \\
\text { Stimulating environment }\end{array}$ \\
\hline $\begin{array}{c}\text { General } \\
\text { impression }\end{array}$ & $\begin{array}{l}\text { V35 } \\
\text { V36 } \\
\text { V37 }\end{array}$ & $\begin{array}{l}\text { Global Image } \\
\text { Personal perception } \\
\text { Society's image } \\
\text { Image compared to other institutions }\end{array}$ \\
\hline
\end{tabular}

These methodological procedures are followed by the presentation and analysis of results. 


\section{PRESENTATION OF RESULTS}

The collected data were tabulated and analyzed using SPSS (Statistical Package for Social Sciences) v. 20. Souza and Baptista (2011) states that verify the data should be the first step for the researcher, because these data will serve as a basis for the analysis of the research to be performed.

Since the questionnaire was composed of three groups of questions, one related to cognitive image, other to affective image and the third, to global image, three steps were observed. In each step, the correlation between the component variables of the scales and the correlation of each of them with the construct in question, was verified. Hair et al. (2005) indicate that a value of $\mathbf{0 . 3 0}$ should be considered significant for the correlation between items, and values greater than 0.50 to correlation of each item with the construct observed.

Data reliability was observed by means of Cronbach's alpha, which verifies the relation of the scale items with the construct or factor to be measured (Rogers, Schmitt \& Mullins, 2002). According to Hair et al (2005), the Cronbach's alpha is significant when its values are greater than $\mathbf{0 , 6 0}$.

Finally, an exploratory factor analysis was performed for cognitive, affective and global images. Aranha and Zambaldi (2008) establish that an exploratory factorial analysis must be performed to verify the one-dimensional of a scale.

\section{Verification of the Global and Affective Image Scales}

First, the global image scales had values to correlation between items above 0.52 ; the correlation of each item with the construct showed values above 0,63 ; and 0.808 to Cronbach's alpha values. In the second step, the affective image showed values above 0.43 to correlation between items; values above 0.53 to correlation of each item with the construct; and 0.763 to Cronbach's alpha.

The first and second steps demonstrated that the Cronbach's alpha values would be reduced if any variable were excluded from the scales. Therefore, based on Hair et al (2005), this means that both scales would have a lower internal consistency. Thus, all the variables remained in the scales, and the factorial analysis was performed.

Factor analysis established the unidimensionality of the scales and that all variables were strongly correlated with the extracted factor, given that the lowest load factor value was 0.782 , with loads equal to or greater than 0.50 being significant (Hair et al., 2005). The variance value, which verifies how much each of the three variables explains the extracted factor (Levine, Stephan, Krehbiel, \& Berenson, 2008), reached values above $68 \%$ for affective image and $72 \%$ for global image and were thus satisfactory for the social sciences (Hair et al., 2005).

The use of factor analysis as a verification technique was adequate, given that the KaiserMeyer-Olkin (KMO) values were 0.705 for global image and $\mathbf{0 . 6 7 4}$ for affective image, with values between 1 and 0.50 being considered acceptable according to Aranha and Zambaldi (2008). The KMO statistic indicates how much a factor explains the observed construct (Hair et al., 2005). The results generated by SPSS confirm the internal reliability and the unidimensionality of the affective and global image scales, thereby creating two 
variables, "Affective Image" and "Global Image", which were condensed through factor analysis.

\section{Verification of Cognitive Image Scale}

The cognitive image scale was verified, in the third step, following the same procedures and seeking to achieve the same objectives as the affective and global image scale verifications. The improvement of services (V31), entrance examination difficulty (V5), and level of competition (V1) variables were removed before performing the factor analysis because their withdrawal increased Cronbach's alpha, which at the end of the process showed a value of 0.906 .

The principal components method with varimax orthogonal rotation was used to perform the factor analysis. Corrar, Paulo e Dias Filho (2009) indicate that in the varimax rotation, are reduced the possibilities of the variables to be related with high factor loadings to more than one factor.

In turn, Reio and Shuck (2015) observe that the principal components method aims to reduce the variables into fewer factors so that they comprise a maximum variance value. Seven factors were studied in the extraction, and the variables were grouped among them as shown below in Table 3.

Table 3. Distribution of variables among the extracted factors

\begin{tabular}{|c|c|c|}
\hline Factors & Label & Variables \\
\hline F01 & Virtual environment & $\begin{array}{l}\text { V10. Ease of use of platform } \\
\text { V09. Ease of access to educational materials } \\
\text { V12. Interface facilitating DL activities } \\
\text { V11. Platform quality }\end{array}$ \\
\hline F02 & Tutors and Staff & $\begin{array}{l}\text { V15. Response time } \\
\text { V16. Trained tutors } \\
\text { V14. Willingness to solve problems } \\
\text { V28. Quality administrative services } \\
\text { V30. Recognition of society }\end{array}$ \\
\hline F03 & Assessment and Content & $\begin{array}{l}\text { V22. Assessments compatible with DL } \\
\text { V21. Consistent assessments } \\
\text { V18. Consistency of disciplines } \\
\text { V19. Curricular program attractive in the } \\
\text { market }\end{array}$ \\
\hline F04 & Teaching Quality & $\begin{array}{l}\text { V23. Course difficulty level } \\
\text { V25. Preparation for the labor market } \\
\text { V27. Quality academic services } \\
\text { V24. Sufficient practical activities }\end{array}$ \\
\hline F05 & Competence & $\begin{array}{l}\text { V13. Correct information } \\
\text { V17. Qualified tutors }\end{array}$ \\
\hline F06 & Communication & $\begin{array}{l}\text { v04. Consistent communication } \\
\text { v03. Effective advertising }\end{array}$ \\
\hline F07 & Innovation and Longevity & $\begin{array}{l}\text { V02. Innovative image } \\
\text { V07. Time of existence }\end{array}$ \\
\hline
\end{tabular}

Source: Research Data (2017) 
Hair et al. (2005) adopt a value of $60 \%$ as the minimum considered satisfactory for explaining total variance. The extracted factors explain $71.29 \%$ of total variance and were determined based on the eigenvalue criterion, in which factors with eigenvalues of less than 1 were eliminated. Corrar, Paulo, and Dias Filho (2009) explain that factors with eigenvalues below 1 are less significant than the original variable.

The most significant factor loadings exceed the value of 0.70 . This demonstrates a welldefined structure in the extraction of factors, which according Costello and Osborne (2005), is the objective of every factor analysis. The final rotation, which met all criteria, is presented below in Table 4.

Table 4. Factors extracted for cognitive image

\begin{tabular}{|c|c|c|c|c|c|c|c|}
\hline Variables & F1 & $\mathbf{F 2}$ & F3 & F4 & F5 & F6 & F7 \\
\hline V02. Innovative image & 0.010 & 0.224 & 0.210 & 0.142 & -0.001 & -0.196 & 0.770 \\
\hline V03. Effective advertising & -0.040 & -0.106 & 0.173 & 0.329 & 0.162 & 0.710 & 0.203 \\
\hline $\begin{array}{l}\text { V04. Consistent } \\
\text { communication }\end{array}$ & 0.090 & 0.216 & 0.141 & 0.094 & -0.164 & 0.849 & -0.068 \\
\hline v07. Time of existence & 0.154 & -0.075 & 0.104 & 0.123 & 0.066 & 0.410 & 0.733 \\
\hline $\begin{array}{l}\text { V09. Ease of access to } \\
\text { teaching materials }\end{array}$ & 0.845 & 0.183 & 0.053 & 0.066 & 0.196 & 0.086 & -0.100 \\
\hline $\begin{array}{l}\text { V10. Ease of use of } \\
\text { platform }\end{array}$ & 0.862 & 0.060 & 0.128 & 0.085 & 0.187 & 0.026 & 0.168 \\
\hline V11. Quality of platform & 0.655 & 0.130 & -0.119 & 0.015 & 0.460 & 0.011 & 0.046 \\
\hline $\begin{array}{l}\text { V12. Interface facilitating } \\
\text { DL activities }\end{array}$ & 0.803 & 0.075 & 0.280 & 0.100 & -0.084 & -0.023 & 0.114 \\
\hline information & 0.246 & 0.144 & 0.328 & 0.125 & 0.735 & -0.021 & 0.118 \\
\hline $\begin{array}{l}\text { V14. Willingness to solve } \\
\text { problems }\end{array}$ & 0.253 & 0.693 & 0.344 & 0.072 & 0.210 & -0.051 & -0.043 \\
\hline ponse time & -0.066 & 0.773 & -0.158 & 0.125 & 0.223 & 0.001 & 0.081 \\
\hline V16. T & 0.119 & 0.696 & 0.180 & 0.073 & -0.072 & -0.023 & -0.068 \\
\hline V17 & 0.180 & 0.299 & 0.168 & 0.248 & 0.688 & -0.053 & -0.047 \\
\hline $\begin{array}{l}\text { V18. Consistency of } \\
\text { disciplines }\end{array}$ & 0.266 & -0.041 & 0.675 & 0.022 & 0.195 & 0.195 & 0.445 \\
\hline $\begin{array}{l}\text { V19. Curricular programme } \\
\text { attractive in the market }\end{array}$ & 0.250 & -0.035 & 0.533 & 0.174 & 0.402 & 0.288 & 0.362 \\
\hline $\begin{array}{l}\text { V21. Consistent } \\
\text { assessments }\end{array}$ & 0.002 & 0.201 & 0.779 & 0.245 & 0.093 & 0.128 & 0.117 \\
\hline $\begin{array}{l}\text { V22. Assessments } \\
\text { compatible with DL }\end{array}$ & 0.141 & 0.187 & 0.796 & 0.187 & 0.125 & 0.078 & 0.038 \\
\hline V23 & 0.126 & 0.015 & -0.045 & 0.822 & 0.139 & 0.179 & 0.123 \\
\hline $\begin{array}{l}\text { V24. Sufficient practical } \\
\text { activities }\end{array}$ & 0.166 & 0.379 & 0.346 & 0.596 & 0.010 & -0.183 & 0.064 \\
\hline $\begin{array}{l}\text { V25. Preparation for labour } \\
\text { market }\end{array}$ & -0.065 & -0.003 & 0.335 & 0.776 & 0.065 & 0.179 & 0.022 \\
\hline $\begin{array}{l}\text { V27. Quality academic } \\
\text { services }\end{array}$ & 0.230 & 0.296 & 0.206 & 0.594 & 0.214 & 0.205 & 0.168 \\
\hline $\begin{array}{l}\text { V28. Quality administrative } \\
\text { services }\end{array}$ & 0.102 & 0.609 & 0.074 & -0.055 & 0.285 & 0.178 & 0.159 \\
\hline V30. Recognition of society & 0.417 & 0.532 & 0.137 & 0.283 & -0.183 & 0.236 & 0.186 \\
\hline
\end{tabular}

\section{ANALYSIS AND DISCUSSION OF RESULTS}

An investigation of the relationship between the affective image and the component factors of the cognitive image and between these and global image was conducted using the "enter" method, aiming to identify those most closely related to the dependent variable using multiple linear regression (Freedman, Fainberg, Kipnis, Midthune \& Carroll., 2004). A simple linear regression was performed to investigate the relationship between the affective and global image. At all times, analysis of variance (ANOVA) had a significance of 0.000 , which according to Hair et al. (2005) indicates that the relationship between the variables cannot be statistically rejected. 
All tests were applied with a $95 \%$ confidence interval, and associations with a p-value below 0.05 were considered significant (Hair et al., 2005). The equations obtained describe the significant relationships between the cognitive, affective, and global images.

In the cognitive image seven factors were raised in the factor analysis. Thus, the results support the studies of Dowling (1986); Barich and Kotler (1991); Palacio, Meneses e Perez (2002); Cervera et al (2012) e Azoury, Daou e Khoury (2014) which demonstrated that the image of higher education institutions is influenced by several variables.

The interactions with the organization create the institutional image (Polat, 2011; da Costa \& Pelissari, 2016), thus the results indicated that, in addition to Affective Image, "Teaching Quality" and "Tutors and Staff" are the most significant factors in such interactions. The study corroborates Boas et al (2011), which emphasizes the need to highlight both pedagogical proposals of institutions and their quality of teaching and learning.

\section{Hypothesis H1}

In order to analyze the hypothesis $\mathrm{H1}$, first, a regression was made between the affective image and the cognitive image factors to identify the existence, nature and the magnitude of the relations between the factors and the affective image. The factors studied for cognitive image were predictive of $58.8 \%$ of the affective image. Considering the seven factors raised for cognitive image, two demonstrated significant relation with the affective image. It is observed in equation 1.

$>$ Equation 1 - Association between Affective Image (AI) and the "Virtual Environment" (VE) and "Teaching Quality" (TQ) factors:

$$
A I=(2.477 E-16)+0.448 \text { "VE" + } 0.237 " T Q "+\varepsilon
$$

Equation 1 indicates that an increase of one point in the perception of VE leads to an increase of 0.448 in the perception of the AI of CEDERJ consortium public education institutions and that the converse is also true. Similarly, the TQ factor is significantly related to AI, and a fluctuation, positive or negative, of one point in TQ causes a fluctuation of 0.237 in the same direction in the perception of AI.

The equation 1 confirms hypothesis $\mathrm{H1}$, indicating the existence of a significant association between cognitive image and AI. According to Palacio, Meneses and Perez (2002) and Cervera et al (2012), which emphasize that feeling related to the organization reflect its intangible aspects and are addressed by affective components, the most significant influence of the VE factor on the $A I$, in the equation 1 , supports the observation of Souza Neto et al (2010), who indicates that the platform used by CEDERJ consortium institutions promotes interactivity and integration among the different groups involved in the teaching-learning process developed by such institutions.

Spindola and Mousinho (2012) point out that the VE is not controlled by institutions. Problems in the platform will be directly reflected in the teaching-learning process in the case of DL and will have possible adverse effects on the student's experience and thus on her perception of the image of the institutions that she attends.

Thus, considering that DL students develop most of their activities in the VE and use this environment to interact with their educational institutions and with other students, it is natural that this factor demonstrated the greatest link with AI. This suggests the importance of establishing and developing a practical platform with a pleasant and userfriendly interface that facilitates effective interaction between its users and the institution. 


\section{Hypothesis $\mathrm{H} 2$}

In order to analyze the hypothesis $\mathrm{H2}$, the same procedures and objectives of the hypothesis $\mathrm{H1}$ were established. It was established that $45.3 \%$ of the global image are predicted by the studied factors raised for the cognitive image. Considering the seven factors, two demonstrated significant relation with the global image. It is observed in equation 2.

$>$ Equation 2 - Association between Global Image (GI) and the TQ and "Tutors and Staff" (TS) factors:

$$
\mathrm{GI}=(-1.416 \mathrm{E}-16)+0.455 \text { "TQ" + } 0.287 \text { "TS" + } \varepsilon
$$

Equation 2 shows that, given the study sample, an increase of one point in the perception of TQ leads to an increase of 0.455 in the perception of the GI of the educational public institutions studied. The reverse is also true. Similarly, the TS factor is significantly associated with GI, with a fluctuation of one point of TS (increase or decrease) causing a fluctuation (increase or decrease) of 0.287 in the perception of GI.

The outcome of this equation confirms hypothesis $\mathrm{H2}$, indicating a significant positive relationship between the cognitive image and the GI. The result indicates the importance of public higher education institutions' highlighting these attributes, seeking to develop mechanisms that ensure the TQ offered by means of a well-designed pedagogical program, the constant search for the qualification and training of their staff and tutors, and the development and maintenance of a practical platform.

Given that the institutions belonging to the consortium are responsible for the pedagogical projects of each course and the coordination of the courses offered, the management of their image is made easier due to such control. The same is true with respect to the preparation of assessments, which is the responsibility of the coordinators of each course, which allows CEDERJ consortium institutions to present a positive corporate image, as noted in this research.

On the other hand, because the tutors are not part of the teaching staff of the CEDERJ consortium institutions (Claro, 2007) and they meet and monitor students (CECIERJ, 2017) and the administrative staff are based in the municipalities where the centers are located, neither the tutors nor the staff are directly linked to the organizational structure (Souza Neto et al, 2010). This non-linkage can reduce their commitment to the performance of activities and negatively affect students' perception in regard to interactions with this component of the image. Unmet expectations in this regard can neutralize or destroy the positive perceptions of the institution, and perfect harmony between all organizational activities is therefore necessary.

Equations 1 and 2 also show that the TQ factor is an important element in the perception of GI, not only because it is one of the constitutive factors of cognitive image, which correlates more closely with GI, but also because it is significantly associated with the AI of the institutions. In this regard and based on the study sample, there are indications that the course's difficulty level, preparation for the labor market, quality academic services and sufficient practical activities, which are all variables relating to this factor, are those that are most instrumental in the perception of both the GI and the AI of the institutions in the case of DL.

Further on the TQ factor, considering that the CEDERJ consortium institutions are responsible for educational project (Souza Neto et al, 2010), as well the coordination of the courses offered to obtain the same quality as that provided in classroom courses (Claro, 2007), managing its image is facilitated due to such control. 
Hypothesis $\mathrm{H} 3$

A simple linear regression was performed to investigate the relationship between the affective image and global image, since a factor analysis revealed the unidimensionality of the affective image scale. The regression revealed that $20.7 \%$ of global image variation was explained by the affective image.

D Equation 3 - Association between GI and AI:

$$
\mathrm{GI}=(-1.061 \mathrm{E}-16)+0.456 \text { "AI" }+\varepsilon
$$

Equation 3 shows that, given the study sample, an increase of one point in the perception of AI leads to an increase of 0.456 in the perception of the GI of the public education institutions studied. The reverse is also true. Thus, for this study sample, hypothesis $\mathrm{H} 3$ can be confirmed because the AI of the public education institutions studied had a significant and positive association with their GI.

Observing the three equations, one can observe that the most significant association with GI is expressed by AI. The result corroborates Azoury, Daou and Khoury (2014), which also point out that the perception of the global image is greatest associated to the affective image.

According to Nguyen and Leblanc (2001), it is suggested that these institutions should adjust aspects of their identity to fit with the beliefs and values of their target public to stimulate favorable feelings in their various interactions, leading to a positive perception of the AI, which will indirectly contribute to the favorable perception of GI. Since there is an interaction of students from different places in the virtual environment (Slavov \& Slavov, 2010), such fact may not be an easy task for the public education institutions studied.

Palacio, Meneses and Perez (2002) indicate that the global image is formed by two interrelated aspects: the cognitive and the affective. Thus, in the present research, the global image was explained by $45.3 \%$ by the cognitive image factors and by $20.7 \%$ by the affective image, totaling $66 \%$. Based on Hair e al (2005) which establishes a value of $60 \%$ as the minimum considered satisfactory for explaining total variance, there are other factors to be considered to explain the others $34 \%$ of the global image.

\section{Hypothesis $\mathrm{H} 4$}

To verify whether the perceptions of GI among incomers and graduates showed significant differences in means from a statistical perspective, the "length of interaction" variable was transformed into a dummy variable. The 85 respondents were considered in every test performed. Incoming respondents assumed the value of 1 and graduates 0 . A $t$ test was conducted, measuring the mean variance for GI and comparing the results between the two sample groups.

Paes (2008) notes that the $t$ test is the most appropriate for detecting differences between means of different groups because it is a parametric test and offers more reliable results. Levine, Stephan, Krehbiel, and Berenson (2008) note that the $t$ test is appropriate even with a small sample $(n<30)$ if the study population has a normal distribution and equal variances and the sample was collected randomly and independently. The test result is shown below in Table 5. 
Table 5. The $t$ test result for samples of incoming and graduating students and their perceptions of the global image of the surveyed higher education institutions.

\begin{tabular}{|c|c|c|c|c|c|}
\hline \multirow{2}{*}{\multicolumn{2}{|c|}{ Global Image }} & \multicolumn{2}{|c|}{$\begin{array}{c}\text { Levine test for equality of } \\
\text { variance }\end{array}$} & \multicolumn{2}{|c|}{$\begin{array}{c}\text { T test for equality of } \\
\text { means }\end{array}$} \\
\hline & & $\mathbf{F}$ & Sig. & $t$ & Sig. \\
\hline Case & $\begin{array}{l}\text { Variance equality accepted } \\
\text { Variance equality not accepted }\end{array}$ & 1.518 & 0.221 & $\begin{array}{l}0.645 \\
0.635\end{array}$ & $\begin{array}{l}0.521 \\
0.528\end{array}$ \\
\hline
\end{tabular}

Source: Research Data (2017)

The SPSS program was used to perform the $t$ test, preceded by the $F$ test, because Levine et al. (2008) note that it is important to test for differences in variances between groups to determine which $t$ test should be applied. The fourth column shows the significance level of the applied test.

Regarding the applied test, $\mathrm{H}_{0}$ corresponds to the case in which the variances are homogeneous, and because the p-value was 0.221 and therefore greater than the 0.05 significance level, equality of variance between the groups was considered to exist. Given this result, the $t$ test showed with $95 \%$ confidence that there are no differences in the manner in which the incoming and graduating respondents in the surveyed sample perceive the GI of the public higher education institutions. This finding means that hypothesis $\mathrm{H} 4$ is rejected because there is no significant difference in the public higher education institutions' GI depending on the length of interaction with the institution.

This result suggests that the image is the result of a decoding of attributes transmitted by institutions in the present, in accordance with Dowling (1986) that emphasizes to be the image an individual perception formed when entering into contact with the institution and Balmer and Grayser (2006), who consider that the corporate image is an answer to the question: "How is the company being perceived now?". In turn, the results are dissonant with Polat (2011) which argues that the image is formed by a process that requires a long period of time.

\section{CONCLUSION}

There are few studies that aim to analyze how public institutions are viewed by their public. This research finds evidence regarding which factors, from the DL student's perspective, are associated with her perception of the public higher education institution's image. It suggests that these institutions should note that the adoption and management of this type of education have peculiarities that, in turn, have repercussions for the institution's general image.

This research corroborates other studies that demonstrate the multidimensionality of image and the fact that it is being formed by cognitive and affective aspects that are both associated with the institution's GI. It shows that the image is a snapshot, generated according to the current stimuli projected by the organization and translated by the public, based on relevant cognitive and affective aspects, according to the individual's manner of observing the environment. Such impressions are affected by internal and external elements, both of the individual who observes and of the organization being observed.

In the study undertaken, the TQ, TS, and VE factors show a significant association with the institution's image. The results indicate the importance of the studied organizations' excelling in these attributes, seeking to develop a plan for the pedagogical project to ensure that sufficient practical activities are offered according to market needs.

Additionally, it is recommended that the tutoring team is well selected, that there is a constant search for the improved qualification and training of staff and tutors, in addition to an appreciation of these professionals, and management of their actions in addressing 
students. Regarding the VE, there is a need to develop and maintain a practical platform with a pleasant interface and that is easy to use, allowing interaction between users and the institution, that does not prejudice the teaching-learning process, and that is nonproblematic in terms of access and use.

In this research, AI proves to be the most expressive of all factors that affect the GI of the analyzed institutions. This finding indicates that the aspects that cannot be directly measured by the institutions are those that most affect the perception of its image, in the case of the DL students covered by the study sample.

The results indicate that in the case of the studied institutions, there was no significant difference in the perceptions of incoming and graduating students. This finding may indicate that for members of an institution's public who are simultaneously exposed to the same reality and under the influence of the same variables, length of interaction has no effect on the perception of the institution's image. An organization's image may therefore change due to aspects of the identity that it projects in the present, in addition to its current relationship with the environment, with competitors, with the market, and with recently met (or unmet) expectations.

The results show that the research objectives were achieved, indicating that there is no contradiction in the application of marketing concepts to the world of the non-profit institution and that they relate not only to its students but to their parents, its internal staff, government agencies, regulatory and funding agencies in maintaining its activities. Thus, this research indicates that studies on image in the marketing field and on the dynamics of DL should be expanded.

One limitation of this study is the application of the questionnaire to students in a single educational center and that all the institutions surveyed belong to the same consortium. It is suggested that a survey should be administered to students who attend DL courses in other centers and at other public institutions. Another limitation is related to the sample size and the particular nature of the covered population, which had a high proportion of non-active students, which resulted in a sample size that was close to the minimum limit established by other studies involving factor analysis.

Future studies should, together with CEDERJ consortium institution students, investigate how the TQ, TS, and VE factors affect the perception of the image of the institutions to which they belong. It is also important to study whether the perception of the institutions' image is affected by its being part of the CEDERJ consortium.

Another suggestion is to consider a more significant sample so that the research results can be generalized. Furthermore, given the peculiarities of public services, another suggestion would be to research private institutions that offer DL courses and to compare the results between institutions.

Finally, given that the models indicate that the variables were responsible for explaining $66 \%$ of the total variance of GI, other elements should be sought in the literature and in real-world observations that may affect the DL student's perception of image. Any such elements found should be included in future research instruments. 


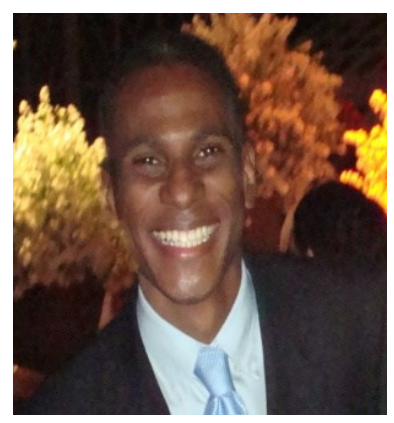

Fabio $R$. da COSTA is currently a professor at the Support Foundation of the Technical School of State Rio de Janeiro and Administrator of State University of Norte Fluminense Darcy Ribeiro. He gained MSc. in Management from the Federal University of Espirito Santo in 2015 and MBA in Business Administration with an emphasis in Information Technology by the Getulio Vargas Foundation in 2007. He has experience in teaching and Administration, focusing on Public Institutions. His academic interest areas are marketing, corporate image, higher education, distance learning and e-learning. The author has articles published in international scientific journals on these areas.

Fabio R. da COSTA

Programa de Pos-Graduacao em Administracao, Universidade Federal do Espirito Santo Federal University of Espirito Santo, 29075910, Vitoria, Espirito Santo, Brazil

Phone: +55 27 4009-2599

E-mail: reis.frc@gmail.com

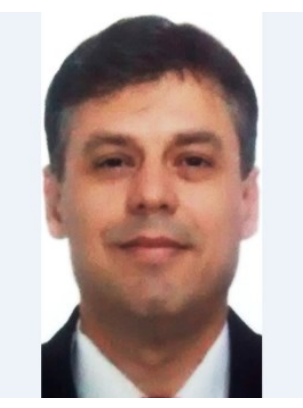

Dr. Anderson S. PELISSARI is an Associate Professor of Marketing of the Department of Administration of the Federal University of Espirito Santo. Dr in Production Engineering, gained his Doctorate at March 2007. His academic interest areas are Marketing and Business Strategies. He has more than 39 articles published in journals, between national and international, papers submitted to national and international journals.

\section{Anderson S. PELISSARI}

Department of Administration, Federal University of Espirito Santo

Federal University of Espirito Santo, 29075910, Vitoria, Espirito Santo, Brazil

Phone: +55 27 99809-0876

E-mail: asoncinipelissari@gmail.com

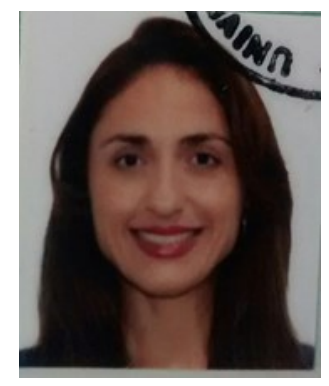

Dr. Inayara V. D. P. GONZALEZ is an Assistant Professor of Innovation of the Department of Administration of the Federal University of Espirito Santo. Dra in Production Engineering gained his Doctorate at December 2014. Her academic interest areas are Strategy, Learning, Innovation and Innovation Management. She has more than 20 articles published in national journals, papers submitted to national and international journals.

Inayara V. D. P. GONZALEZ

Department of Administration, Federal University of Espirito Santo

Federal University of Espirito Santo, 29075910, Vitoria, Espirito Santo, Brazil

Phone: +55 27 99944-0253

E-mail: gonzalezinayara@gmail.com 


\section{REFERENCES}

Aranha, F., \& Zambaldi, F. (2008). Analise Fatorial em Administracao. Sao Paulo, BR: Cengage Learning.

Azoury, N., Daou, L., \& Khoury, C.E. (2014). University image and its relationship to student satisfaction: Case of the Middle Eastern private business schools. International Strategic Management Review, 2(1), 1-8.

Balmer, J. M. T., \& Grayser, S. A. (2006). Corporate marketing integrating corporate identity, corporate branding, corporate communications, corporate image and corporate reputation. European Journal of Marketing, 40(7/8), 730-741.

Barich, H., \& Kotler, P. (1991). A framework for marketing image management. MIT Sloan Management Review, 32(2), 94-104.

Berens, G., \& Van Riel, C. B. M. (2004). Corporate associations in the academic literature: Three main streams of thought in the reputation measurement literature. Corporate Reputation Review, $7(2), 161-178$.

Bielschowsky, C. E. (2005). Educacao superior a distancia do consorcio CEDERJ: Centro de educacao superior a distancia do estado do Rio de Janeiro. In: Oliveira, F. B. (Ed.). Educacao corporativa. Sao Paulo, BR: Pearson - Prentice Hall.

Boas, A. A. V., de Andrade, G. H. N., Hamtini, T., \& de Sousa, S. A. (2011, April). Tutors and university teachers' perception about quality assurance in distance learning: The case of the undergraduate management course in Minas Gerais - Brazil. In: Global Engineering Education Conference (EDUCON). 2011, (679-684). IEEE.

BRASIL. (2005). Decreto no 5.622, de 19 de dezembro de 2005. Retrieved from http://www.planalto.gov.br/ccivil_03/_ato20042006/2005/decreto/d5622.htm.

Camelia, G., \& Marius, P. (2013). Incorporating market orientation in higher education institutions. Annals of the University of Oradea, Economic Science Series, 22(1), 1743-1752.

CECIERJ - Fundacao Centro de Ciencias e Educacao Superior a Distancia do Estado do Rio de Janeiro. (2017). Regulamento dos cursos de graduacao do consorcio CEDERJ. Retrieved from http://www.unirio.br/cead/editais/arquivosnoticias/regulamento-dos-cursos-de-graduacao-do-consorcio-cederj.

CEDERJ - Centro de Educacao Superior a Distancia do Estado do Rio de Janeiro. (2017). Consorcio CEDERJ. Retrieved from http: //cederj.edu.br/cederj.

Cervera, A., Schlesinger, W., Iniesta, M. A., \& Sánchez, R. (2012). Medicion de la imagen de la universidad y sus efectos sobre la identificacion y lealtad del egressado: Uma aproximacion desde el modelo de Beerli y Diaz (2003). Revista Espanola de Investigacion em Marketing ESIC, 16(2), 7-29.

Chin, W. W., Marcolin, B. L., \& Newsted, P. T. (2003). A Partial least squares latent variable modeling approach for measuring interaction effects: Results from a Monte Carlo simulation study and voice mail emotion/adoption study. Information Systems Research, 14(2), 189-217.

Claro, T. (2007). A docencia no consorcio CEDERJ: Interatividade ou transmissao. In: Encontro de Educacao e Tecnologias da Informacao e da Comunicacao. 2007. ETIC.

Corrar, L. J.; Paulo, E., \& Dias Filho, J. M. (2009). Analise multivariada para os cursos de administracao, ciencias contábeis e economia. 1th., Sao Paulo, BR: Atlas.

Costa, C. J. (2007). Modelos de educacao superior a distancia e implementacao da Universidade Aberta do Brasil. Brazilian Journal of Computer in Education, 15(2). 
Costello, A. B. \& Osborne, J. W. (2005). Best practices in exploratory factor analysis: four recommendations for getting the most from your analysis. Practical Assessment, Research \& Evaluation. 10(7).

da Costa F. R. , \& Pelissari, A. S. (2016). Factors affeting corporate image from the perspective of distance learning students in public higher education institutions. Tertiary Education and Management, 22(4), 287-299.

da Costa Vieira, P. R., \& Couto, R. D. R. B. (2015). Escala para avaliacao de imagem corporativa de universidade com capital aberto: Um estudo com modelagem de equacões estruturais. Revista de Administracao IMED, 5(1), 98-112.

Dowling, G. R. (1986). Managing your corporate images. Industrial Marketing Management, 15(2), 109-115.

Freedman, L. S., Fainberg, V., Kipnis, V., Midthune, D., \& Carroll, R. J. (2004). A new method for dealing with measurement error in explanatory variables of regression models. Biometrics, 60, 172-181.

Garland, R. (1991). The mid-point on a rating scale: Is it desirable? Marketing Bulletin, 2(1), 66-70.

Hair, J. F., Anderson, R. E., Tatham, R. L., \& Black, W. C.(2005). Multivariate data analysis, 6th ed., New Jersey: Pearson.

Harsono, S. (2014). The institution image and trust and their effect on the positive word of mouth. International Research Journal of Business Studies, $\pi(1), 69-78$.

INEP - Instituto Nacional de Estudos e Pesquisas Educacionais Anisio Teixeira. (2015). Censo da educacao superior 2014. Retrieved from http://www.inep.gov.br

Kauffman, H. (2015). A Review of predictive factors of student success in and satisfaction with online learning. Research in Learning Technology, 23(1).

Kucuksuleymanoglu, R. (2015). Organizational image perceptions of higher education students. Educational Research and Reviews, 10(20), 2667-2673.

Kundi, G. M., Nawaz, A., \& Khan, S. (2010). The predictors of success for e-learning in higher education institutions (HEIs) in N-W.F.P, Pakistan. Journal of Information Systems and Tecnology Management, $7(3)$, 545-578.

Lakatos, E. M, \& Marconi, M. A. (2010). Fundamentos de metodologia cientifica. 7th ed., Sao Paulo, BR: Editora Atlas.

Levine, D. M., Stephan, D., Krehbiel, T. C., \& Berenson, M. L.(2008). Estatistica: Teorias e aplicacoes. Rio de Janeiro, BR: LTC.

Malhotra, N. K. (2011). Pesquisa de marketing: Uma orientacao aplicada. 3th. ed. Sao Paulo, BR: Editora Pearson Prentice Hall.

Martineau, P. (1958). The personality of the retail store. Harvard Business Review, 36(1), 47-55.

MEC - Ministerio da Educacao e Cultura. (2001) CNE: Apresentacao. Retrieved from http://portal.mec.gov.br/cne/arquivos/pdf/2001/pces966_01.pdf

Mondini, V. E. D., Mondini, L. C., da Rosa Borges, G., \& de Souza Domingues, M. J. C. (2014). Instituicoes de ensino superior a distancia: Analise dos motivos de escolha. Revista Meta: Avaliacao, 6(16), 71-84.

Moran, J. M. (2010). Avaliacao do ensino superior a distancia no Brasil. Retrieved from http://www2.eca.usp.br/moran/wp-content/uploads/2013/12/avaliacao.pdf

Nguyen, N., \& Leblanc, G. (2001). Corporate image and corporate reputation in customers' retention decisions in services. Journal of Retailing and Consumer Services, 8(4), 227-236.

Paes, A. T. (2008). Por dentro da estatistica. Einstein: Educ. Contin. Saude, 6(1), 107-108. 
Palacio, A. B., Meneses, G. D., \& Perez, P. J. P. (2002). The configuration of the university image and its relationship with the satisfaction of students. Journal of Educational Administration, 40(5), 486-505.

Polat, S. (2011). The relationship between university student's academic achievement and perceived organizational image. Educational Sciences: Theory \& Practice, 1(11), 257-262.

Reio, T. G., \& Shuck, B. (2015). Exploratory factor analysis: Implications for theory, research, and practice. Advances in Developing Human Resources, 17(1), 12-25.

Richardson, R. J. (1999). Pesquisa social: Metodos e tecnicas. 3th Ed., Sao Paulo, BR: Editora Atlas, 336 p.

Rindfleisch, A., Malter, A. J., Ganesan, S., \& Moorman, C. (2008). Cross-sectional versus longitudinal survey research: Concepts, findings and guidelines. Journal of Marketing Research, 45(3), 261-279.

Rogers, W. M., Schmitt, N. \& Mullins, M. E. (2002). Corrections for unreliability of multifactor measures: Comparison of alpha and parallel forms approaches. Organizational Research Methods, 5(2), 184-199.

Slavov, B., \& Slavov, R. (2010). Educacao a distancia, uma nova modalidade de ensino e a legislacao brasileira. Revista Sapere, 2(1).

Souza, M. J.\& Baptista, C. S. (2011). Como fazer investigacao, dissertacoes, teses e relatorios segundo Bolonha. 2th. Ed., Lisboa, PT: Pactor - Lidel.

Souza Neto, S. P.; Dias, T. R. F. V.; Boas A. A. V.; Brito, A. G., \& Leite, G. S. M. (2010). Fatores de qualidade: Pontos positivos do emprego da tecnologia DL no curso de administracao do consorcio CEDERJ - UFRRJ. In: Congresso Internacional Abed de Educacao a Distancia. 2010. CIAED.

Spindola, M., \& Mousinho, S. H. (2012). CEDERJ: Um caminho na direcao da educacao inclusiva. Revista Cientifica em Educacao a Distancia, 1(2), 36-46.

Tran, M. A., Nguyen, B. Melewar, T. C., \& Bodoh, J. (2015). Exploring the corporate image formation process. Qualitative Market Research: An International Journal, 18(1), 86-114.

Tubillejas, B., Cuadrado, M., \& Frasquet, M. (2011). A model of determinant attributes of corporate image in cultural services. Nonprofit and Voluntary Sector Quarterly, 40(2), 356-376.

Wilkins, S., \& Huisman, J. (2013). Student evaluation of university image attractiveness and its impact on student attachment to international branch campuses. Journal of Studies in International Education, 17(5), 607-623.

Yener, D. (2013). Students' perceived service quality of distance learning course in a dual-mode education system. Contemporary Educational Technology, 4(1), 5065.

Yin, R. K. (2015). Estudo de Caso: Planejamento e Metodos, 5th Ed., Porto Alegre, BR: Bookman Editora. 